\title{
Organizational Trust, Risk and Creativity
}

\section{Confiança Organizacional, Risco e Criatividade}

Confianza Organizacional, Riesgo y Creatividad

\section{Ana Filipa Correia Rodrigues ${ }^{1}$ Ana Luísa de Oliveira Marques Veloso ${ }^{2}$}

Received on June 18, 2012 / Approved on November 14, 2013

Responsible Editor: João Maurício Gama Boaventura, Dr.

Evaluation Process: Double Blind Review

\begin{abstract}
The competitiveness has guided companies to an investment in creativity as a means of innovation. Organizational trust has a positive impact in organizations, leading to an increase in cooperation, creativity and innovation. We start with the question: can trust in leadership influence the behaviour of employees to risk more new ideas? 244 employees of different functional arear and levels of work seniority participated in this study. We detected that there is a positive relationship between trust and behaviour to provided new ideas. Employees from nonproductive areas have higher levels of trust in leadership and as such take more risks in creating new ideas, than direct employees.
\end{abstract}

Keywords: Creativity. Organizational trust. Risk.

\section{RESUMO}

A competitividade direcionou as empresas na aposta da criatividade como meio da inovação. A confiança organizacional tem um impacto positivo nas organizaçóes, promovendo a cooperação, a criatividade e a inovação. Partimos da questão: será que a confiança na chefia é suscetível de influenciar o comportamento dos colaboradores em arriscar mais novas ideias? Deste estudo participaram 244 sujeitos de diferentes áreas funcionais e tempo de trabalho. Verificou-se uma relação positiva entre confiança e comportamento de arriscar novas ideias. Os colaboradores indiretos têm maiores níveis de confiança na chefia e arriscam mais novas ideias do que os diretos.

Palavras-chave: Criatividade. Confiança organizacional. Risco.

\section{RESUMEN}

La competitividad impulsó a las organizaciones a apostar por la creatividad como medio de innovación. La confianza organizacional tiene un impacto positivo en las organizaciones,

1. Doctoral student of Occupational and Organizational Psychology at School of Psychology from Universidade do Minho, Portugal. [filipa.c.rodrigues@gmail.com]

2. Doctor in Occupational and Organizational Psychology from Universidade do Minho, Portugal. [alveloso@psi.uminho.pt] Authors' addresses: Escola de Psicologia, Universidade do Minho - Campus de Gualtar, Braga, Portugal 4710-057 
promoviendo la cooperación, creatividad e innovación. Partimos de la cuestión: ¡la confianza en los jefes podría influir en el comportamiento de los empleados a la hora de arriesgar a proponer nuevas ideas? En el estudio participaron 244 individuos de diferentes áreas funcionales y con distinta antigüedad. Se comprobó que existía una relación entre la confianza y el riesgo al proponer nuevas ideas. Los empleados indirectos tienen un mayor nivel de confianza en los jefes y arriesgan más con nuevas ideas a diferencia de los empleados directos.

Palabras clave: Creatividad. Confianza organizacional. Riesgo.

\section{INTRODUCTION}

With the increase in competitiveness and resulting abandonment of traditional production methods, organizations are seeking to innovate. However, in order to do that, they need to bet on their human resources potential and establish a favorable climate for the emergence of creativity as a means of innovation (ZHOU, HIRST, SHIPTON, 2012). Therefore, it is necessary to promote trust, which will trigger commitment in employees, who will feel more connected to the organization (SOUSA, 2000). Trust entails risk, as who trusts is in a vulnerable, uncertain position in relation to the person who is the target of such trust (MAYER, DAVIS, SCHOORMAN, 1995). Also, creativity involves risks, as when the perception thereof is high and the trust relationship with the superiors is not established, employees will hardly feel they have the autonomy to contribute with new ideas for the organizational success (SOUSA, 2000).

In this study, trust is understood as a multidimensional construct, as characteristics of the person who trusts and of the person who is trusted, as well as the work context in which the relationship takes place, are considered.
This paper aimed to study organizational trust as it relates to risk. More specifically, we intended to perceive how the trust level in superiors influenced the behaviors of employees in risking new ideas.

\section{TRUST}

Trust in organizations has caused interest in researchers of several fields. In the studies we conducted, we found trust is related to (NELSON, QUICK, 2003), communication (BECERRA, GUPTA, 2003; PORUMBESCU, PARK, OOMSELS, 2013), control mechanisms (DAS, TENG, 1998; KHODYAKOV, 2007; REED, 2001), risk (EARL, 2010; LIU, WANG, 2013) and creativity and innovation (BARSH, CAPOZI, DAVIDSON, 2008; GARCÍACRUZ; REAL, 2013; KOHTAMÄKj; KEKÄLE, VIITALA, 2004).

Baird and St. Amand (1995) and Sako (1998) state that trust leads to increased productivity, reduced absenteeism and turnover, and promotes a favorable environment to creativity and innovation. On the other hand, lower levels of trust are related to increased stress in the organization, reduced productivity and less commitment to the company (BAIRD, ST. AMAND, 1995), and constraints to innovation (KERN, 1998). In this case, communication is restricted, as information is not appropriately shared and, when it is, people do not trust it. With no trust, there is no team work and employees work towards their own benefit (RÍO, 2001).

While most studies focus on superiors' trust in their employees, Mayer and Gavin (2005) analyze employees' trust in top management. They detected that trust in management makes employees focus more on tasks that add value to the organization and that trust in leadership is more related to the organizational citizenship behaviors that to individual performance.

The organizational trust study involves some constraints, more specifically regarding the 
definition of construct, gaps in clarification of the trust-risk relationship (FREIRE, 2007; MAYER DAVIS; SCHOORMAN, 1995) and difficulty in distinguishing antecedents and outcomes of trust (MAYER, DAVIS, SCHOORMAN, 1995). These two last aspects can be explained by the model proposed by Mayer et al. in 1995, as described below.

Investigators have not reached a consensus in defining the concept of trust, but perspectives converge in understanding it as a multidimensional phenomenon (GANESAN, HESS, 1997; DAS, TENG, 2001). Trust can be studied at the interpersonal, organizational and multidimensional levels. In this regard, Ganesan and Hess (1997) developed a study whereby they detected that trust in sellers (interpersonal trust) is more related to commitment than trust in the organization (organizational trust). They detected that trust based on organizational benevolence predicts more commitment than interpersonal benevolence (GANESAN, HESS, 1997). This study validated the hypothesis that trust should be construed as a multidimensional construct.

Among the most significant research conducted at the multidimensional level, we point out the integrative model of organizational trust proposed by Mayer, Davis and Schoorman (1995), according to which trust is established in the center of an interpersonal relationship, between a trusting party (trustor) and a party to be trusted (trustee), and involves risks, as one of the parties acknowledges and previously accepts their existence in the relationship and that the vulnerable position inherent in the trustor means that something of value can be lost.

The model distinguishes trust and its antecedents, based on the assumption that the trustor agrees to be vulnerable to the trustee, based on willingness to trust and on the perception that the other party deserves to be trusted. The model also differentiates trust from its outcomes, which encompass the behavior to take risks in relation to the other party (MAYER, DAVIS, SCHOORMAN, 1995).
This model considers that a trust relationship relies on a set of variables, which comprise characteristics of the two parties involved in such relationship (MAYER, DAVIS, SCHOORMAN, 1995). The trustor is willing to trust, which understood as a natural characteristic, a tendency of the individual to trust. Such willingness remains relatively stable over the time and is previous to the establishment of the relationship with the trustee. The willingness to trust is, alone, insufficient for a trust relationship to be established, which also relies on characteristics of the trustee, i.e., trustworthiness factors (MAYER, DAVIS, SCHOORMAN, 1995). Other authors integrate the three most accepted factors: ability, benevolence and integrity. Ability is that set of knowledge and technical skills of an individual that make them trustworthy within some specific domain. Benevolence is the extent to which a trustee is willing to go good to the trustor, aside from any personal benefit. Integrity is related to the trustor's perception that the trustee adheres to a set of principles that the trustor finds acceptable. The consistency of the party's actions, such as whether they are congruent with his or her words, or the belief that the trustee has a strong sense of justice, affect the degree to which the trustee's integrity is judged by the trustor (MAYER, DAVIS, SCHOORMAN, 1995).

Each of these factors is variable, irrespective of the others, but they are all interconnected and shall coexist for a trust relationship to be established. Trustworthiness shall be construed as a continuum, as antecedents may exist in a higher or lower number. The time dimension is important in understanding these factors, as integrity is central to begin establishing a relationship (as the ability, it is quickly learnt and formed in the trust relationship), but benevolence seems to be more important at a later stage and is built in a more slowly way over the relationship (MAYER, DAVIS, SCHOORMAN, 1995).

According to the integrative model authors, the risk is a central element in any trust model, as there is no risk in the willingness 
of being vulnerable, but it is implied in the behavioral expression of the willingness to be vulnerable. Therefore, trust can be seen as "the willingness to take a risk" (p. 724) and behavioral trust is taking a risk. The outcome of trust is "risk taking in relationship" (RTR), as it includes the interaction between two parties (MAYER, DAVIS, SCHOORMAN, 1995).

Even though the level of trust may be constant, by combining the willingness to trust and trustworthiness factors, the specific consequences of trust seem to be determined by contextual factors (stakes involved, the balance of power in the relationship, the perception of the level or risk and alternatives available to the trustor) (MAYER, DAVIS, SCHOORMAN, 1995). Similarly, the assessment of the antecedents of trust seems to be affected by the context. Thus, the trustor perception and interpretation of the context of the relationship will affect both the need for trust and the evaluation of trustworthiness (MAYER, DAVIS, SCHOORMAN, 1995). A strong organizational control system could inhibit the development of trust, because a trustee's actions may be interpreted as responses to that control rather than signs of trustworthiness (MAYER; DAVIS; SCHOORMAN, 1995).

This model mainly presents three gaps: its focus is limited to trust of a specific trustor for a specific trustee; trust is considered as unidirectional, not designed to examine the mutual development between two parties; it is focused on trust in an organizational context, and may not be generalized to other contexts (MAYER, DAVIS, SCHOORMAN, 1995).

The model presented in 1995 was revised by Schoorman, Mayer and Davis (2007), who propose the inclusion of new domains considered to be involved in trust: emotion (which affects trustworthiness factor perception) and culture (trust may vary according to the culture).

\section{TRUST, RISK AND CREATIVITY}

The risk can be understood as involving decision taking, wherein one can take the risk or not (SLOVIC, PETERS, 2006). For Sitkin and Pablo (1992), we are at risk when there is uncertainty as to the outcome of our decisions, when we do not know whether they will be significant or not.

In this study, risk is understood at the interpersonal level, as it is implied in the trust relationship between superiors and employees. As referred to above, the Mayer, Davis and Schoorman (1995) model infers that, based on trust, on how the individual perceives risk and on gains and losses anticipated, such individual may or may not take the risk in the relationship. Without risk there is no question of mentioning trust, as there is no vulnerability or expectations in relation to the other person (KEATING, SILVA; VELOSO, 2010).

The research revealed that there is a negative relationship between trust and risk perception (MCLAIN, HACKMAN, 1999), i.e., the higher the trust individuals place on the other party, the less they perceive the risk involved in the relationship, as the more trustworthy the trustee is, fewer losses are expected when taking a risk in the relationship.

The creativity concept does not seem to have a consensus among authors. A widely accepted definition is proposed by Stein (1974, p. 35), according to which creativity is a "process that results in a novel product that is accepted by a significant group of others as useful, tenable or satisfying at some point in time." Nevertheless, this definition was criticized by its subjective nature (SOUSA, 2000).

Even though the complexity inherent in the very concept - creativity should be understood as a multidimensional object (MORAIS, 1999) - for this study, creativity is considered as "the generation of new and useful ideas" (AMABILE, 1997 , p. 40). With this definition, we do not intend to be reductionist, or neglect all cognitive processes underlying creative thinking, but limit the field of action of this investigation.

More studies have already been developed around creativity and innovation, but 
distinguishing these concepts can still be difficult. Although they are supplementary processes, they report to different phenomena, as creativity is related to the generation of new ideas, whereas innovation is related to the implementation of such ideas (OHLY; OSONNENTAG; PLUNTKE, 2006). In the organizational context, creativity is a process of cognitive-emotional nature, essentially individual, whereas innovation is a social process. Notwithstanding, innovation seems to come from the individual creativity, and this is where concepts converge (SOUSA, 2000). Thus, creativity seems to be a necessary condition for innovation to successfully take place (BASSETT-JONES, 2005). As reported by Lin (2011), successful organizations create competitive edge by transforming the creativity of their people in organizational innovation.

Creativity being understood as a process arising from a social interaction context (AGGARWAL, BHATIA, 2011), for creativity and innovation to take place in organizations it is essential that a favorable climate for their development exists, to promote a creative climate (EKVALL, 1996), in which motivation, dynamism, freedom are present / autonomy to make decisions, trust, time for ideas/humor, support for new ideas from colleagues and superiors, debates, risk taking, among other variables (ALENCAR, BRUNO-FARIA, 1997; DUL, CEYLAN, 2011 ; EKVALL, 1996; SHALLEY, ZHOU, OLDHAM, 2004; WANG, XUE; SU, 2010; ZHOU; HIRST; SHIPTON, 2012).

The relationship between trust and creativity has been subject to several investigations. Barsh, Capozi and Davidson (2008) study showed that trust plays a central role in generating new ideas. According to Axtell et al. (2000), personal characteristics, such as creativity and work control, affect the suggestion of ideas and the implementation thereof requires the existence of support climate. Also for García-Cruz and Real (2013), the existence of support and collaboration are central factors for innovation to exist.
Alongside, Cabra, Talbot and Joniak (2005, p. 69) state that trust is one of the elements that have been cited in studies on the creative climate. For the authors, this is understood as "the perception that people in the organization are trustworthy," which seems to indicate integrity and honesty, as it is believed that people in the company are able, competent and honest to perform their tasks. Thus, trust requires delegation of duties, acceptance of extra responsibilities by employees and that employees fulfill their promises. The leadership style seems to contribute to leverage the possibility of employees risking new ideas, as when people feel respected by their superiors, they are more likely to submit their ideas (CABRA, TALBOT, JONIAK, 2005; ESCRIBÁ-ESTEVE, MONTOROSÁNCHEZ, 2012).

In this article, the trust relationship is considered bottom-up, i.e., from employees to their superiors. Thus, just as Mayer, Davis and Schoorman (1995), this study is also based on the principle that trust exists in the context of a relationship. In fact, literature has shown that trust appears as a pre-condition to the establishment of interpersonal relationships (ESPEJO, 2001).

As referred to above, trust is understood as a multidimensional construct. Trust of the employee in his leadership depends as much on their willingness to trust as the perception the employee has on the ability, integrity and benevolence of their leadership. The higher the perception that the superiors are trustworthy, the more likely employee is expected to trust them.

One of the factors introduced by Mayer, Davis and Schoorman (1995) in their trust model was the risk, which is also fundamental. If the employee anticipates that their ideas are welcomed by superiors, whether based on previous contacts, whether because they consider themselves to be able to perceive suggestions, the employee is likely to contribute new ideas.

Hypothesis 1: There will be a positive relationship between superiors and employees' behavior in risking new ideas. 
Based on that employees with higher level of trust in their superiors realize risks less in the relationship with them and risk more new ideas. The behavior of risk taking can be influenced either by contextual factors (which may affect the employee's evaluation of superiors' trustworthiness), or by superiors' variables. Such factors may be related to the control systems or to the leadership style of the superiors, and will interfere in the employee's perception of risk, by influencing their behavior of taking risks or not, or new ideas.

Literature considers two types of control: the formal control (standards and procedures established to monitor and reward desirable performance) and social control (which seeks to establish a common culture philosophy and values) (DAS, TENG, 2001). Thus, a formal control may limit a trust relationship and the social control may encourage the development of trustworthiness relationships (DAS, TENG, 2001).

Both social and formal controls may influence risk perception, which can also be affected by other contextual factors. A system dependent on variables such as autonomy, information available, shared leadership and openness to others (DEWETT, 2007) may lead to less perception of risk, which will increase the likelihood of an employee taking risks in the relationship, and giving more ideas to their superiors. Conversely, if such a climate of support does not exist, the greater the risk perceived and the less the employee is likely to risk new ideas. In fact, in the organizational context, hierarchical relationships usually produce control, as when superiors do not see their employees as autonomous. In this situation, employees see their space of action restricted and, as a result, reduce their performance (ESPEJO, 2001). Although companies seem willing to bet on creativity, they live a dilemma: on the one hand, they want their employees to be free to have more creative potential; on the other, they have to control their actions (KHODYAKOV, 2007).

In short, it is expected that when employees perceive their leadership as trustworthy, and when control mechanisms in their areas are not too strong, they are more likely to risk new ideas, as the perceive less risk in the relationship. Conversely, when control mechanisms are too strong, risk perception will be higher, and it is very likely that employees will be unwilling to contribute new ideas. In addition, employees' previous attempts to contribute suggestions are important, as, if welcomed with greater satisfaction, employees are more likely to risk new ideas, since risk perception of risk is lower.

Trust has been recognized as key to creativity, to generate new ideas (CABRA, TALBOT, JONIAK, 2005; SOUSA, 2000). Also support seems to contribute to employees expressing more their ideas (EISENBERG, FASOLO, DAVIS-LAMASTRO, 1990). Support is related to the creative climate proposed by Ekvall (1996), who suggests that the higher the level of trust in a company, the greater the openness felt by the employees to produce their ideas.

Hypothesis 2: There will be differences in risk taking given the functional area.

Hypothesis 3: There will be differences in the level of trust in superiors given the functional area.

In the company where this study was conducted, the functional area is subdivided into productive (direct labor) and non-productive (indirect labor). The concern in involving this variable was the understanding of the outcome of a previous organization creative climate assessment, which revealed such climate was different according to the functional area (RODRIGUES, 2008b). We detected that direct labor has less autonomy, less space to participate in the decision-taking processes and express opinions, as compared to indirect labor. Therefore, we understand that direct labor presents less behaviors related to risking new ideas, mainly due to lack of opportunity to do so (RODRIGUES, 2008b).

Such results may be combined with those of Dodd and Ganster (1996), who evidenced 
that autonomy in the workspace may increase employees' satisfaction. As a result, more satisfied employees are more engaged in their work, and such engagement may lead to new ideas (SOUSA, 2000). Therefore, the existence of autonomy and freedom to generate new ideas and take decisions in the workplace seem to be significant to promote creativity in the organizations (COELHO, AUGUSTO, LAGES, 2011; DUL, CEYLAN, 2011; ZHOU, HIRST, SHIPTON, 2012).

Furthermore, productive areas are related to more repetitive tasks, more routine work. The investigators' position with respect to the relation existing between routine and creativity differs. If for some, creativity and routine are two incompatible elements (WEST, 2002), for others (OHLY, SONNENTAG, PLUNTKE, 2006), there is a positive relationship between these two concepts. In this study, we consider that routine in productive areas can have a negative impact on the employees' behavior of risking new ideas. Thus, we expect that there is a difference between direct labor and indirect labor at the level of trust in superiors and the behavior or risking new ideas. We tend to believe that indirect labor will have a behavior of risking more new ideas and place more trust in the superiors than direct labor.

Hypothesis 4: There will be a positive relationship between seniority in the company and the perception of trust in superiors.

Hypothesis 5: There will be a positive relationship between seniority in the company and the behavior of risking new ideas.
The seniority variable was studied in an attempt to understand whether people with greater seniority in the firm risk more new ideas and have a greater perception of the trustworthiness of their superiors. This organizational variable can test one of Mayer, Davis and Schoorman (1995) model assumptions, whereby trustworthiness is perceived over the time, first with perception of ability and integrity and then the perception of benevolence. In a recent study conducted by Schoorman, Mayer and Davis (2007), just as detected by Schoorman (2002), the authors continue to reinforce the importance of time for the establishment of a trust relationship, with perception of ability and integrity being more easily acquired, and the perception of benevolence arising only at a later stage. Only with time can employees truly understand if their superiors are benevolent to them without expecting any personal reward. Thus, employees who have been working longer in the company are expected to have greater perception of trustworthiness in relation to their superiors, as they have already had the time to gather the information they need to perceive them as trustworthy or not.

As regards risk taking, literature reveals that creativity tends to decrease over time (MORAIS, 1999), as employees with more seniority (related to age in this study) are expected to have fewer behaviors of risking new ideas. 


\section{METHOD}

\section{I Subjects}

This quantitative study, descriptive and correlational in nature, relied on the participation of 244 subjects (136 male and 108 female), and

TABLE 1 - Social and demographic characterization of the sample

\begin{tabular}{ccc}
\hline Variable & $\mathbf{N}$ & $\%$ \\
\hline Gender & 136 & 55,7 \\
Men & 108 & 44,3 \\
Women & & \\
Age & 40 & 16,4 \\
20 to 29 y.o. & 51 & 20,9 \\
30 to 39 y.o. & 86 & 35,2 \\
40 to 49 y.o. & 66 & 27,0 \\
50 to 59 y.o. & 1 & 0,4 \\
Over 60 y.o. & & \\
Education & 71 & 29,1 \\
$1^{\text {st }}$ cycle & 44 & 18,0 \\
$2^{\text {nd }}$ cycle & 84 & 34,4 \\
$3^{\text {rd }}$ cycle & 32 & 13,1 \\
High school & 9 & 3,7 \\
Higher course & 4 & 1,6 \\
Other & &
\end{tabular}

\subsection{Tools}

For this study, we used a questionnaire intended to assess the organizational trust and the risk of generating new ideas. The questionnaire comprises an initial part of social and demographic data collection (i.e., gender, age and academic qualifications) and organizational data (i.e., seniority in the company, area of work and shift).

The tool used to assess organizational trust comprises questions related to trustworthiness factors, willingness to trust and level of trust. We used a version in Portuguese of the Mayer and Davis questionnaire (1999, translated and validated for the Portuguese population by is in the median class between 40 and 49 years of age. In academic qualifications, the median is in the third cycle. Participants were from productive $(\mathrm{n}=121)$ and non-productive $(\mathrm{n}=123)$ areas, 220 from day shift and 15 from night shift. Seniority in the company ranged from 1 to 42 years $(\mathrm{M}=20.25, \mathrm{dp}=11.65)$.

TABLE 2 - Characterization of the work situation of the sample

\begin{tabular}{ccc}
\hline Variable & n & $\%$ \\
\hline Work shift & & \\
$1^{\text {st }}$ shift (morning) & 48 & 19,7 \\
$2^{\text {nd }}$ shift (afternoon) & 48 & 19,7 \\
$3^{\text {rd }}$ shift (night) & 15 & 6,1 \\
$4^{\text {th }}$ shift (regular) & 124 & 50,8 \\
Other & 7 & 2,8 \\
Without information & 2 & 0,8 \\
Work seniority & 3 & \\
Less than 3 years & 101 & 4,2 \\
3-16 years & 130 & 53,4 \\
Over 16 years & 10 & 4,10 \\
Without information & & \\
Functional area & 121 & 49,9 \\
Productive areas & 123 & 50,4 \\
Non-productive areas & &
\end{tabular}

Source: the authors.

Keating, Silva and Veloso, 2010). Each item has a 5-point Likert-like answer scale, with 1 being "Strongly Disagree" and 5 "Strongly Agree."

As regards the tool to measure the behavior or employees to risk new ideas, we adapted a set of items added to the "risk new ideas" scale, 5 of which taken from Ekvall (1996) questionnaire, Creative Climate Questionnaire. This questionnaire comprises a set of items related to the taking-risk factor and assesses the perception of employees on the organizational climate supporting their creativity, by means of the ten domains referred to above|. It has fifty questions to be answered in a Likert-like scale from 0 to 3 points (0: disagree; 3: strongly agree). In the measurement used for this study, we integrated items assessing risk 
taking. We adapted the response scale from 4 to 5 options, such as the tool used to assess trust. Questions were prepared in order to capture the opinion of employees about their superiors. In addition to these five items, we developed another way to include a contextual question in the questionnaire. In short, this scale has an implicit assessment of how superiors use their employees' ideas, how they support them and reinforce them (RODRIGUES, 2008a).

\section{PROCEDURE}

Data was collected from a textile company in the district of Braga, Portugal. Participants were randomly selected from a population of 681 employees who do not hold management offices. 253 employees were selected, with a proportion between productive and non-productive areas. We distributed 253 questionnaires, of which $98.8 \%$ were returned. The questionnaires with more than $10 \%$ of the answers not completed were eliminated. In total, 244 questionnaires were considered valid.

Participation in this study was voluntary and answer confidentiality ensured.

\section{RESULTS}

Data was analyzed through the statistics program Statistical Package for Social Sciences (SPSS, version 11 for Mac Os X).

As regards the tool used to assess organizational trust, data analysis started by conducting a factorial and exploratory analysis and a feasibility analysis. The factorial and exploratory analysis in significant components with varimax rotation revealed that, in the ability domain, the six items considered were saturated in a single component. The same analysis revealed that the 12 items regarding benevolence and integrity were saturated in a single component. This resulted in a single component comprising ten items. The factorial analysis conducted with the eight items comprising willingness to trust revealed the existence of two components, one of which comprising two inverted items, which were excluded. This construct was reduced to six items. The analysis of 10 items in the trust dimension revealed a component comprising only 5 items.

The feasibility analysis (internal consistency) of components resulting from the factorial analysis revealed an alpha of Cronbach of 0.92 for the ability component, and 0.93 for the benevolence/integrity component. In both situations, internal consistency is considered very good, in accordance with Pestana and Gageiro (2005). As for the willingness to trust component, a 0.70 Cronbach alpha was revealed, whereas for the trust component, a 0.64 Cronbach alpha was revealed, and considered "weak" by the same authors.

In order to realize the relationship among the items defined foe each "risk new ideas" scale, we conducted a factorial and exploratory analysis of the main components with varimax rotation. The result obtained for the KaiserMeyer-Olkin (KMO) test was 0.86 for which the analysis of main components was considered good (PEREIRA, 2006). The importance level of the Bartlett test was 0.000, which reveals the existence of a significant correlation $(\mathrm{p}<0.05)$ among components (PESTANA, GAGEIRO, 2000). These results enable the continuation of the factorial analysis. The resulting component explains the $59.27 \%$ in total variance, whose degree of saturation ranged from 0.71 to 0.83 .

Based on the results obtained in the factorial analysis, we analyzed the internal consistency of the component studied, through the Cronbach alpha which revealed internal consistency of 0.86 , which is classified as good (PESTANA, GAGEIRO, 2005).

In order to test Hypothesis 1, we used the Spearman correlation ratio, which revealed a positive correlation, statistically significant, between trust in superiors and the behaviors of employees in risking new ideas, i.e., employees with more trust in their superiors tend to risk more new ideas $(r=0.37, p<0.001)$. This data confirm the hypothesis considered.

In Hypothesis 2, the Mann-Whitney test revealed that there are statistically significant 
differences at the level of behavior of risking new ideas due to the area in the company. In non-productive areas, employees risk more new ideas than in productive areas $(\mathrm{z}=-2.88, \mathrm{p}<0.05)$.

TABLE 3 - Results of the Mann-Whitney difference test between non-productive and productive areas, in relation to the behavior or risking new ideas

\begin{tabular}{cccc}
\hline & $\begin{array}{c}\text { Non-productive areas } \\
\mathbf{N = 1 2 3}\end{array}$ & $\begin{array}{c}\text { Productive areas } \\
\mathbf{N}=\mathbf{1 2 1}\end{array}$ & $\mathbf{Z}$ \\
\hline Risking new ideas & 135,36 & 10943 & $-2.88^{*}$ \\
\hline
\end{tabular}

${ }^{*} \mathrm{p}<0.05$

Source: the authors.

In Hypothesis 3, the Mann-Whitney test revealed that there are statistically significant differences at the level of trust in superiors given the employees' area in the company. In non-productive are, employees trust their superiors more than in productive areas $(\mathrm{z}=-$ 3.03, $\mathrm{p}<0.01)$. Thus, both hypotheses have been validated.

TABLE 4 - Results of the Mann-Whitney difference test between non-productive and productive areas, in relation to trust

\begin{tabular}{cccc}
\hline & $\begin{array}{c}\text { Non-productive areas } \\
\mathbf{N}=\mathbf{1 2 3}\end{array}$ & $\begin{array}{c}\text { Productive areas } \\
\mathbf{N}=\mathbf{1 2 1}\end{array}$ & $\mathbf{Z}$ \\
\hline Trust & 135,94 & 108,84 & $-3,03^{* *}$ \\
\hline
\end{tabular}

** $\mathrm{p}<0.01$

Source: the authors.

In hypothesis 4, the Spearman correlation ratio revealed that there is no statistically significant relation between seniority in the company and the perception of superiors' ability $(r=0.13$, n.s. $)$. Likewise, it revealed that there is no statistically significant correlation between seniority in the company and the perception of benevolence and integrity of superiors $(r=0.11$, n.s.). These results indicate that hypothesis 4 could not be validated. In Hypothesis 5, the Spearman correlation ratio revealed a statistically significant positive correlation between seniority and the behavior of employees in risking new ideas, i.e., more senior employees tend to risk more new ideas $(r=0.13, p<0.05)$, but the relation between the two variables is quite low.

\section{DISCUSSION}

The results seem to evidence the relevance of the Mayer, Davis and Schoorman (1995) model for this research. We detected that, the higher the trust placed in the superiors, the greater the behavior of employees' risking new ideas. What seems to be implied in this result is that employees perceive less risk in relation to their hierarchical superior, which contributes to their risking more new ideas. This process may be influenced by factors such as leadership style, control mechanisms and other variables, as the risk taking in the relationship is dependent whether on the trust relationship, or on risk perception. However, both may be influenced by the contextual factors, as explained by Mayer, Davis and Schoorman (1995). The results found converge with the studies conducted by Barsh, Capozzi and Davidson (2008) and Sommer and Pearson (2007), who detected that trust is an important factor for employees to feel willing to express their ideas.

In this study, we analyzed two organizational variables. One of them was the 
functional area of employees, which was divided into productive and non-productive areas. The results revealed that indirect labor risk more new ideas and place more trust in superiors that direct labor, which proved the researched hypotheses.

These results can be explained by several factors. On the one hand, productive areas are subject to higher levels of routine, which may inhibit employees in their expressing new ideas, as referred to by West (2002), to whom creativity and routine are incompatible. On the other hand, direct labor seems to be subject to lower levels of autonomy and a lower level of engagement in the decision-taking processes (RODRIGUES, 2008a). According to several authors (COELHO; AUGUSTO; LAGES, 2011; EKVALL, 1996; ZHOU; HIRST; SHIPTON, 2012), autonomy and participation in the decision-taking process are important factors to promote creative climate. When such climate exists, new ideas appear spontaneously. Another factor that could be advanced in the explanation of this result is related to the leadership style. Research has shown that the leadership style exercised may preclude employees' creativity when power is used as an instrument to obtain employees' submission (LEE, 1997). Recent studies evidence that leadership and, specifically, transformational leadership, positively influences innovating behavior, i.e., the willingness to generate and implement new ideas (SANDERS; SHIPTON, 2012).

Likewise, participation in the decisiontaking process may explain the differences found in the level of trust given the employees functional area. According to Mishra and Morrissey (1990), when employees participate in the decision-taking process, the level of trust increases, which is in line with the results obtained. These revealed that indirect labor place more trust in superiors than direct labor. Also, we have already stated that in non-productive areas, employees have more autonomy to take decisions, which leads to more trust in superiors.

Another element that can explain the results found is that indirect labor is relatively closer to superiors, i.e., communicates more with them, feels more open to express ideas, especially because such new ideas tend to appear more often in this area of work. On the other hand, direct labor, given the characteristics underlying their area of work (e.g.: time pressure, domain), feels les close to superiors, which may be the reason for the trust relationship not have been built. Openness is precisely one of the trustworthiness factors that have been mentioned in some research (BUTLER, 1991). Although Mayer, Davis and Schoorman (1995) did not integrate this factor to their model, it is important to explain these results, as openness, as mentioned by Butler (1991), is related to the fact that the trustee (superiors) adopts an open position to new ideas and shows to be available for other people's suggestions. We believe that the existence of superiors who are open to new ideas proposed by their employees is perceived as more trustworthy, which may contribute to higher levels of trust in the relationship. This openness seems to be essentially present in non-productive areas (RODRIGUES, 2008a), which explains the results obtained.

The other organizational variable studied was the seniority of employees in the company. We intended to check its relationship with the behavior of risking new ideas and the perception for superiors' trustworthiness. The results did not contribute to validate the two hypotheses proposed in this regard. Based on the Mayer, Davis and Schoorman (1995) assumption, as to the time dimension of trustworthiness characteristics, we expected a positive relationship between them and seniority in the company, which did not happen. Furthermore, the results arrived at through the Spearman correlation ratio showed that perception of ability is much closer to a significant relationship with seniority $(\mathrm{r}=$ 0.13 , n.s.). If it existed, this correlation would be considered weak, and very far in relation to the other two factors considered (benevolence and integrity). This data seems to converge with that presented by Davis et al. (2000), who showed that the three trustworthiness factors were related to trust, but only integrity and benevolence are significant in the regression analysis. This evidences some degree of separation of ability in relation to other trust antecedents. 
The inexistence of a relationship between seniority and perception of trustworthiness may be explained by the interference of contextual factors (corporate restructuring) in interpersonal relationships. Several participants questioned the researcher whether the questionnaire results would be revealed to their superiors. The fear of not keeping their jobs may have affected their commitment to the work. The commitment can be understood in the affective sense (emotional attachment to the organization), duration (recognition of costs related to leaving the organization) or norm (sense of obligation to stay in the organization) (MEYER, IRVING, ALLEN 1998). The duration commitment may be a possible explanation to the results arrived at. Given the contextual interference, several participants may not be engaged in the company and the only reason for not leaving is that they anticipate the costs underlying such decision. Such participants may express duration commitment and then not be interested in establishing a trust relationship with their superiors. Indeed, the research evidences that there is no positive relationship between duration commitment and organizational trust (TANNER, 2007).

The duration commitment may have some participants not risk new ideas, as they are more concerned about the results of their leaving the organization. Creativity implies engagement (SOUSA, 2000), which is not obtained through this commitment. The almost inexistent relationship between risking new ideas and seniority is contradicted by Siegrist, Gutscher and Earle (2005), who showed that, the older the person (which is correlated to the seniority in our sample), the more risk is perceived. Based on this result, we expected that more senior employees would risk fewer ideas, but, although the relationship found between risk and seniority was significant, it is considered too weak to be considered.

At last, it is suggested that one factor may have been based on the lack of differences between seniority and the behavior of risking new ideas, and between seniority and trust, which was the fact that there is a great uniformity in terms of seniority in the company where the data were collected.

This research has some limitations. First, upon collecting data, the questionnaire used to measure trust was still in a validation phase for the Portuguese people, which may have biased data. The sample used in this study was considered for the validation of the instrument in the Portuguese context. Second, we did not consider contextual factors that could measure or control the relationship between trust in superiors and the generation of new and useful ideas, such as the incentive system, leadership or intrinsic motivation. Finally, some participants had changed superiors at the data collection time, which may have been a restriction, as in these cases, we could not relate seniority and perception of trustworthiness, for example.

\section{CONCLUSION AND FUTURE IMPLICATIONS}

Literature shows that trust seems to be a factor that promotes creativity, which was evidenced by our research.

This study left some hints that need further investigation. The Mayer, Davis and Schoorman (1995) model suggests that contextual factors influence the behavior of taking risks in the relationship. Also, we considered context significance and, therefore, it would be interesting to analyze how this affects risk perception and trustworthiness perception, namely leadership. It would also be interesting to study the relationship between trustworthiness perception and the behavior of risking new ideas, considering seniority, in other companies operating in the same industry, and compare employees with different levels of seniority (different types of contract). Finally, this study was based on an interpersonal relationship with specific superiors. It would be important to study it further in a more macro-contextual dimension.

This research has three important theoretical contributions with implications for the practice in organizations. First, we evidenced 
the importance of organizations thinking of the need to establish strategies that promote trust and creativity of productive area employees, as creativity depends on their willingness to change, to create new things (PATON, MCCALMAN, 2008). All employees can be, at a higher or lower level, creative, irrespective of the nature of their jobs, provided that certain personal and environmental conditions are met (AMABILE, 1997).

Second, this research highlighted the importance to consider contextual factors, such as any mediators or moderators in the relationship between trust and creativity. For the employees to generate new ideas, placing trust in superiors is not enough. It is also important to consider other variables and the means where the relationship takes place.

At last, this paper contributed to highlight the importance of trust for the organizational context in general, and the contribution for creativity in particular. Companies usually intend to bet on innovation, but seem to neglect that this means personal development of their employees. For innovation to take place, employees need to feel a facilitating climate, that the can express their individual creativity, and contribute with new ideas for the organization's system interest. This study showed how important it is to develop trust in interpersonal relationships, which reveals that, perhaps, companies should reach this level before betting on creativity and innovation.

\section{REFERENCES}

AGGARWAL, Y.; BHATIA, N. Creativity and innovation in management: a fuel for growth. International Journal of Multidisciplinary Research, [S.1.], v. 1, n. 5, p. 288-296, Sept. 2011.

ALENCAR; E. M. L. S.; BRUNO-FARIA, M. F. Characteristics of an organizational environment which stimulate and inhibit creativity. Journal of Creative Behavior, Buffalo, v. 31, n. 4, p. 271-281, Dec. 1997.
AMABILE, T. Motivating creativity in organizations: on doing what you love and loving what you do. California Management Review, Berkeley, v. 40, n. 1, p. 39-58, Fall 1997.

AXTELL, C. et al. Shopfloor innovation: facilitating the suggestion and implementation of ideas. Journal of Occupational and Organizational Psychology, London, v. 73, n. 3, p. 265-285, Sept. 2000.

BAIRD, A.; ST. AMAND, R. Trust within the organization. Ottawa, CA: Public Service Commission of Canada, 1995.

BARSH, J.; CAPOZZI, M.; DAVIDSON, J. Leadership and innovation. Mckinsey Quarterly, New York, v. 1, p. 36-47, Jan. 2008. Disponível em: <http://www.mckinseyquarterly.com>. Acesso em: 22 maio 2008.

BASSETT-JONES, N. The paradox of diversity management, creativity and innovation. Creativity and Innovation Management, Chichester, v. 14, n. 2, p. 169-175, June 2005.

BECERRA, M.; GUPTA, A. Perceived trustworthiness within the organization: the moderating impact of communication frequency on trustor and Trustee Effects. Organization Science, Linthicum, v. 14, n. 1, p. 32-44, 2003.

BUTLER, J. Toward understanding and measuring conditions of trust: evolution of a conditions of trust inventory. Journal of Management, Thousand Oaks, v. 17, n. 3, p. 643-663, Sept. 1991.

CABRA, J. F.; TALBOT, R. J.; JONIAK, A. J. Exploratory study of creative climate: a case from selected Colombian companies and its implications on organizational development. Cuadernos Administración, Bogotá, v. 18, n. 29, p. 53-86, enero/jun. 2005.

COElHO F.; AUGUSTO M.; LAGES L. F. Contextual factors and the creativity of frontline employees: the mediating effects of role stress and 
intrinsic motivation. Journal of Retailing, New York, v. 87, n. 1, p. 31-45, Mar. 2011.

DAS, T. K.; TENG, B. Between trust and control: developing confidence in partner cooperation in alliances. Academy of Management Review, New York, v. 28, n. 3, p. 491-512, July 1998.

Trust, control, and risk in strategic alliances: an integrative framework. Organization Studies, Berlin, v. 22, n. 2, p. 251-283, Mar. 2001. Disponível em: <http:// findarticles.com/p/articles/mi_m4339/is_2_22/ ai_76668287/>. Acesso em: 30 maio 2008.

DAVIS, J. M. et al. The trusted general manager and business unit performance: empirical evidence of a competitive advantage. Strategic Management Journal, Chichester, v. 21, n. 5, p. 563-576, May 2000.

DEWETT, T. Linking intrinsic motivation, risk taking, and employee creativity in a $R \& D$ environment. R\&D Management, Oxford, v. 37, n. 3, p. 197-208, June 2007.

DODD, N; GANSTER, D. C. The interactive effects of variety, autonomy, and feedback on attitudes and performance. Journal of Organizational Behavior, West Sussex, v. 17, n. 4, p. 329-347, July 1996.

DUL, J.; CEYLAN, C. Work enviroments for employee creativity. Ergonomics, Thousand Oaks, v. 54, n. 1, p. 12-20, Jan. 2011.

EARL, T. C. Trust in risk management: a modelbased review of empirical research. Risk Analysis, New York, v. 30, n. 4, p. 541-574, Apr. 2010.

EISENBERGER, R.; FASOLO, P.; DAVISLAMASTRO, V. Perceived organizational support and employee diligence, commitment, and innovation. Journal of Applied Psychology, Washington, v. 75, n. 1, p. 51-59, Feb. 1990.

EKVALL, G. Organizational climate for creativity and innovation. European Journal of Work and Organizational Psychology, vol. 5, pp.105-123, 1996.
ESCRIBÁ-ESTEVE, A.; MONTOROSÁNCHEZ, A. Guest editorial: creativity and innovation in the firm: managerial antecedents and effects on employees. International Journal of Manpower, Bradford, v. 33, n. 4, p. 344-348, 2012.

ESPEJO, R. Auditing as a Trust Creation Process. Systemic Practice and Action Research, New York, v. 14, n. 2, p. 215-236, Apr. 2001.

FREIRE, C. M. F. C. Confiança: determinantes e implicaçóes em equipas de I\&D. 2007. 276 f. Tese (Doutorado em Ciências Empresariais)-Escola de Economia e Gestão, Universidade do Minho, Braga, 2007.

GANESAN, S.; HESS, R. Dimensions and levels of trust: implications for commitment to a relationship. Marketing Letters, Dordrecht, v. 8 , n. 4, p. 439-448, Oct. 1997.

GARCÍA-CRUZ, J.; REAL, J. C. Confianza como consecuencia del compromiso percibido: implicaciones sobre el aprendizaje y la innovación. Cuadernos de Gestión, Bilbao, v. 13, n. 1, p. 95-124, 2013.

KEATING, J.; SILVA, I.; VELOSO, A. Confiança organizacional: teste de um modelo. In: SIMPÓSIO NACIONAL DE INVESTIGAÇÃO EM PSICOLOGIA, 7., 2010, Braga. Anais... Braga: Associação Portuguesa de Psicologia, 2010. p. 2451-2466.

KERN, H. Lack of trust, surfeit of trust: some causes of the innovation crisis in German industry. In: LANE, C.; BACHMANN, R. (Eds.). Trust within and between organizations: conceptual issues and empirical applications. New York: Oxford University Press, 1998. p. 203-213.

KHODYAKOV, D. M. The complexity of trustcontrol relationships in creative organizations: insights from a qualitative analysis of a conductorless orchestra. Social Forces, Baltimore, v. 86, n. 1, p. 1-21, Sept. 2007. 
KOHTAMÄKI, M.; KEKÄLE, T.; VIITALA, R. Trust and innovation: from Spin-Off Idea to stock exchange. Creativity and Innovation Management, Oxford, v. 13, n. 2, p. 75-87, June 2004.

LEE, B. The power principle. New York: Simon Schuster, 1997.

LIN, L. Electronic human resource management and organizational innovation: the roles of information technology and virtual organizational structure. The International Journal of Human Resource Management, London, v. 22, n. 2, p. 235-257, 2011.

LIU, X.; WANG, Z. Perceived risk and organizational commitment: the moderating role of organizational trust. Social Behavior \& Personality: An International Journal, Palmerston North, v. 41, n. 2, p. 229-240, Feb. 2013.

MAYER, R. C.; DAVIS, J. H. The effect of the performance system on trust for management: a field quasi-experiment. Journal of Applied Psychology, Washington, v. 84, n. 1, p.123-136, Feb. 1999.

; SCHOORMAN, F. D.

An integrative model of organizational trust. Academy of Management Review, Briarcliff Manor, v. 20, n. 3, p. 709-734, July 1995.

; GAVIN, M. B. Trust in management and performance: who minds the shop while the employees watch the boss? Academy of Management Journal, New York, v. 48, n. 5, p. 874-888, Oct. 2005.

MCLAIN, D. L.; HACKMAN, K. Trust, risk, and decision-making in organizational change. Public Administration Quaterly, London, v. 23, n. 2, p. 152-176, Summer 1999.

MEYER, J. P.; IRVING, P. G.; ALLEN, N. J. Examination of the combined effects of work values and early work experiences on organizational commitment. Journal of Organizational Behavior, West Sussex, v. 19, n. 1, p. 29-52, Jan. 1998.

MISHRA, J.; MORRISSEY, M. A. Trust in employee/employer relationships: a survey of West Michigan managers. Public Personnel Management, Washington, v. 19, n. 4, p. 443486, Dec. 1990.

MORAIS, M. F. Definiçáa e avaliação de criatividade: contributos da perspectiva cognitiva. 1999. 527 f. Tese (Doutorado em Psicologia)Universidade do Minho, Braga, 1999.

NELSON, D. L.; QUICK, J. C. Organizational behavior: foundations, realities \& challenges. 4 th ed. Cincinnati, OH: Thompson South Western, 2003.

OHLY, S.; SONNENTAG, S.; PLUNTKE, F. Routinization, work characteristics and their relationships with creative and proactive behaviors. Journal of Organizational Behavior, West Sussex, v. 27, n. 3, p. 257-279, May 2006.

PATON, R. A.; MCCALMAN, J. Change management, a guide to effective implementation. 3rd ed. Thousand Oaks, CA: Sage, 2008.

PEREIRA, A. Guia prático de utilização do SPSS: análise de dados para ciências sociais e psicologia. 4. ed. Lisboa: Ed. Sílabo, 2006.

PESTANA, M. H.; GAGEIRO, J. N. Análise de dados para ciências sociais: a complementaridade do SPSS. 4. ed. Lisboa: Ed. Sílabo, 2005.

PORUMBESCU, G.; PARK, J.; OOMSELS, P. Building trust: communication and subordinate trust in public organizations. Transylvanian Review of Administrative Sciences, ClujNapoca, Romania, n. 38, p. 158-179, 2013.

REED, M. I. Organization, trust and control: a realist analysis. Organizations Studies, Berlin, v. 22, n. 2, p. 201-228, Mar. 2001. 
RÍO, S. J. M. La confianza y la participación al interior de las organizaciones. Santiago do Chile: Pontifícia Universidad Católica de Chile (Escuela de Ingeniería), 2001.

\section{RODRIGUES, F. C. Confiança organizacional,} risco e criatividade. 2008. 229 f. Dissertação (Mestrado em Psicologia do trabalho e das Organizações) - Universidade do Minho, Braga, 2008a.

Relatório de estágio. Mestrado em Psicologia do trabalho e das Organizações. Braga: Universidade do Minho, 2008b.

SAKO, M. Does trust improve bussiness performance? In: LANE, C.; BACHMANN, R. (Eds.). Trust within and between organizations: Conceptual issues and empirical applications. New York: Oxford University Press, 1998. p. 88-117.

SANDERS, K.; SHIPTON, H. The relationship between transformational leadership and innovative behaviour in a healthcare context: a team learning versus a cohesion perspective. European Journal International Management, [S.1.], v. 6, n. 1, p. 83-100, 2012.

SCHOORMAN, F. D. Integrative trust perspectives: foundations for a revised integrative model of organizational trust. In: ANNUAL MEETING OF THE ACADEMY OF MANAGEMENT, 62., Denver, USA. Anais... New York: AOM, 2002.

; MAYER, R. C.; DAVIS, J. H. An integrative model of organizational trust: past, present and future. Academy of Management Review, Briarcliff Manor, v. 32, n. 2, p. 344-354, Apr. 2007.

SHALLEY, C. E.; ZHOU, J.; OLDHAM, G. R. The effects of personal and contextual characteristics on creativity: where should we go from here? Journal of Management, Thousand Oaks, v. 30, n. 6, p. 933-958, Nov. 2004.
SIEGRIST, M.; GUTSCHER, H.; EARLE, T. C. Perception of risk: the influence of general trust, and general confidence. Journal of Risk Research, London, v. 8, n. 2, p. 145-156, 2005.

SITKIN, S. B.; PABLO, A. L. Reconceptualizing the determinants of risk behavior. The Academy of Management Review, Briarcliff Manor, v. 17, n. 1, p. 9 -38, Jan. 1992.

SLOVIC, P.; PETERS, E. Risk perception and affect. Current Directions in Psychological Science, Malden, v. 15, n. 6, p. 322-325, Dec. 2006.

SOMMER, A.; PEARSON, C. M. Antecedents of creative decision making in organizational crisis: A team-based simulation. Technological Forecasting \& Social Change, New York, v. 74, n. 8, p. 1234-1251, Oct. 2007.

SOUSA, F. C. A criatividade e a inovação na gestão das organizaçôes. Revista Portuguesa de Gestáo, Lisboa, v. 15, n. 2, p. 44-50, 2000.

STEIN, M. I. Stimulating creativity. New York: Academic Press, 1974.

TANNER, B. M. JR. An analysis of the relationship among job satisfaction, organizational trust, and organizational commitment in an acute care hospital. 2007. 164 f. Tese (Doctor of Philosophy in Organizational Systems)-Faculty of Saybrook Graduate School and Research Center, San Francisco, 2007. Disponível em: <http:// gradworks.umi.com/32/66/3266765.html>. Acesso em: 30 maio 2008.

WANG, D.; XUE, H.; SU, H. Influence of work support on employee creativity: an empirical examination in the peoples Republic of China. African Journal of Business Management, [S.1.], v. 4, n. 8, p. 1546-1553, July 2010.

WEST, M. A. Sparkling fountains or stagnant ponds: an integrative model of creativity and innovation implementation in work groups. 
Applied Psychology: An International Review, Oxford, v. 51, p.355 424, 2002.

ZHOU, Q.; HIRST, G.; SHIPTON, H. Context matters: combined influence of participation and intellectual stimulation on the promotion focus-employee creativity relationship. Journal of Organizational Behavior, West Sussex, v. 33, n. 7, p. 894-909, Oct. 2012. 